\title{
FAKTOR DETERMINAN KESIAPAN PERAWAT DI DUA RUMAH SAKIT DAERAH BANTEN DALAM PENUGASAN KEBENCANAAN
}

\author{
Wiwin Winarti, Laksita Barbara \\ Program Studi Keperawatan, Fakultas Ilmu Kesehatan \\ Universitas Pembangunan Nasional Veteran Jakarta
}

\begin{abstract}
ABSTRAK
Karakteristik geografis dan iklim Indonesia menjadikannya negara yang rawan bencana. Provinsi Banten merupakan daerah multirawan bencana antara lain gempa, tsunami, banjir, longsor, dan abrasi. Dengan tingginya jumlah bencana yang terjadi, kesiap-siagaan bencana tentu saja harus menjadi prioritas di Provinsi Banten, terutama dalam hal mitigasi bencana dan kesiapan bantuan kesehatan di daerah bencana untuk mengurangi korban jiwa maupun angka kesakitan. Penelitian ini menggunakan desain crossectional yang melibatkan 136 perawat dari dua RSUD di Banten yaitu RSUD Drajat Prawiranegara dan RSUD Banten. Metode yang digunakan adalah kuisioner JDNREI yang diapatasi kedalam Bahasa Indonesia dan disebarkan secara online kepaa responden. Hasil penelitian menunjukkan bahwa variable jenis kelamin secara statistic berhubungan dengan domain Keterampilan keperawatan gawat darurat, keterampilan praktis tanggap bencana, dan keterampilan komunikasi dalam kesiapsiagaan bencana perawat $(p<0,05)$. Kesimpulan: Jenis kelamin merupakan factor dominan yang berpengaruh dalam kesiapsiagaan bencana. Saran: Pelatihan terkait keterampilan dalam enam domain kesiapsiagaan bencana perlu dilakukan pada semua perawat.
\end{abstract}

Kata kunci: kesiapsagaan, perawat, bencana

\begin{abstract}
The characteristics of Indonesia's geographic and climate make Indonesia prone to disaster. Banten Province is a disaster-prone area, including earthquakes, tsunamis, floods, landslides, and abrasions. With the high number of disasters occurring, disaster preparedness must be a priority in Banten Province, especially in terms of disaster mitigation and readiness for health care providers including nurses in disaster areas to reduce casualties and morbidity. This study used a cross-sectional design involving 136 nurses from two hospitals in Banten, namely Drajat Prawiranegara Hospital and Banten Hospital. The method used was the JDNREI questionnaire, which was adapted into Bahasa Indonesia and distributed online to respondents. The results showed that the gender variable was statistically related to the domain of emergency nursing skills, disaster response, practical skills, and communication skills disaster preparedness for Nurses $(p<0.05)$. Conclusion: Gender is the dominant factor that influences disaster preparedness. Suggestion: skills-related training in the six disaster preparedness domains needs to be carried out for all nurses.
\end{abstract}

Keywords: readiness, nurse, disaster

Alamat Korespondensi: Fakultas Ilmu Kesehatan, Universitas Pembangunan Nasional Veteran Jakarta, Jalan Limo Raya Kelurahan Limo Kecamatan Limo Kota Depok Kode Pos 16515

Email: wiwin.winarti@upnvj.ac.id

\section{PENDAHULUAN}

Karakteristik geografis dan iklim Indonesia menjadikannya negara yang rawan bencana. Pada tahun 2019 telah tercatat hampir dua ribu kejadian bencana terjadi di Indonesia dengan kejadian bencana tertinggi berpusat di pulau jawa (Badan Nasional Penanggulangan Bencana, 2019b). Dilihat dari jumlah korban meninggal dan luka-luka, gempa bumi dan tsunami menjadi 
urutan pertama dari bencana alam yang terjadi di Indonesia (Badan Nasional Penanggulangan Bencana, 2019a). Provinsi Banten sendiri merupakan daerah multirawan bencana antara lain gempa, tsunami, banjir, longsor, dan abrasi (Soleman, Nurcahyani, \& Munajati, 2012). Tsunami selat Sunda terjadi di akhir tahun 2018 dan Kabupaten Serang merupakan salah satu daerah yang terdampak (Cipta, 2018). Pada awal tahun 2020, banjir dan longsor juga terjadi di kabupaten Lebak dan menyebabkan sejumlah korban tewas, dan ratusan rumah rusak sehingga perlu mengungsi (Nazmudin, 2020). Tingginya jumlah bencana yang terjadi menjadikan kesiap-siagaan bencana prioritas di Provinsi Banten, terutama dalam hal mitigasi bencana dan kesiapan bantuan kesehatan di daerah bencana untuk mengurangi korban jiwa maupun angka kesakitan. RSUD Dr. Adjidarmo dan RSUD Dr. Dradjat Prawiranegara merupakan rumah sakit pemerintah dimana tenaga kesehatan, khususnya perawat, memiliki peranan penting dalam penugasan tenaga kesehatan ke wilayah bencana.

Kesiap-siagaan penugasan kebencanaan dari perawat seringkali dititik-beratkan pada kesiapan kompetensi terutama dalam keterampilan klinis dan keperawatan. Namun, bencana merupakan kejadian yang tidak terduga yang menyebabkan perawat harus mengambil keputusan yang cepat dengan berbagai keterbatasan dan tekanan (Raveis, VanDevanter, Kovner, \& Gershon, 2017). Stresor dan tanggung jawab yang besar dalam situasi bencana tentunya akan mempengaruhi kesehatan jiwa perawat sehingga resiliensi secara psikologi penting untuk mendapat perhatian. Perawat perlu memiliki kesiapan baik secara keterampilan kegawatdaruratan dan kebencanaan maupun kemampuan koping dan adaptasi sehingga memiliki resiliensi yang baik dalam penugasan kebencanaan. Perawat sebagai tenaga kesehatan merupakan garda terdepan dalam manajemen bencana. Namun, data tentang kesiapan perawat dalam penugasan kebencanaan di Indonesia sangat terbatas. Beberapa penelitian telah dilakukan berkenaan dengan kesiapan tenaga kesehatan khususnya perawat dalam penugasan di daerah bencana. Salah satu penelitian menemukan rendahnya kesiapan perawat Pusat Kesehatan Masyarakat (Puskesmas) di daerah Bantul walaupun perawat telah dibekali pelatihan kegawatdaruratan (Huriah \& Farida, 2010). Penelitian tersebut menggunakan pendekatan kualitatif dimana hasil dari penelitian memiliki beberapa keterbatasan dalam generalisasi hasil serta objektifitas pengukuran. Penelitian dengan pendekatan kuantitatif juga telah dilakukan pada mahasiswa keperawatan di Purwokerto yang didapatkan bahwa kesiapan kebencanaan juga rendah (Rizqillah, 2019). Namun, gambaran kesiapan penugasan bencana pada perawat yang secara objektif dengan instrumen holistik yang akurat belum diketahui.

\section{METODE PENELITIAN}

Penelitian ini menggunakan desain observasional dengan pendekatan deskriptif kuantitatif dengan metode pengumpulan data secara survei. Populasi dari penelitian ini adalah perawat Rumah Sakit Umum Daerah (RSUD) Dr. Adjidarmo dan RSUD Dr. Dradjat Prawiranegara di Provinsi Banten. Survei dilakukan menggunakan adaptasi instrument yang dikembangkan oleh Maeda, Kotera, Matsuda, \& Huebner (2018). Instrumen ini telah dikembangkan untuk mengkaji aspek kesiapan penugasan kebencanaan secara holistik dan telah disesuaikan untuk perawat. Selain mengkaji keterampilan perawat dalam kebencanaan dan kegawat-daruratan, aspek keterampilan komunikasi, kemampuan adaptasi terhadap lingkungan bencana, koping terhadap stress, dan kooperasi juga dikaji secara menyeluruh dalam instrument tersebut. Instrumen ini juga telah memenuhi uji validitas dan reliabilitas dalam versi Bahasa Jepangnya. Oleh karena itu, instrument ini dipilih karena sesuai dengan perkembangan dan kebutuhan dalam manajemen bencana saat ini.

Korespondensi dilakukan dengan pengembang instrument untuk memastikan legalitas penggunaan instrumen. Instrumen tersebut akan diterjemahkan dan diadaptasi ke dalam Bahasa 
Indonesia. Uji validitas dilakukan dengan berkonsultasi pada 3 ahli dibidang kegawatdaruratan dan bencana melalui email dengan instrument penilaian yang disediakan peeliti.

Peneliti merekrut responden dengan menggunakan total sampling dari perawat yang bekerja di RSUD Dr. Adjidarmo dan RSUD Dradjat Prawiranegara, Banten. Sampel penelitian adalah seluruh perawat di semua unit di kedua rumah sakit tersebut yang memenuhi kriteria yang ditetapkan sejumlah 136 perawat. Rekrutmen dilakukan setelah peneliti menjelaskan secara terbuka tentang tujuan, prosedur penelitian, dan manfaat penelitian serta hak-hak dari responden. Kerahasiaan identitas responden akan dijaga dengan tidak mencantumkan kolom identitas pribadi (nama dan alamat) pada kuisioner. Responden berhak menolak berpartisipasi tanpa konsekuensi apapun. Kriteria inklusi dari responden antara lain perawat dengan minimal pendidikan D3 Keperawatan dan bekerja di RSUD Dr. Adjidarmo dan RSUD Dradjat Prawiranegara, status perawat dari pegawai kontrak maupun pegawai tetap dapat menjadi responden. Sedangkan kriteria eksklusi antara lain perawat yang merupakan tenaga magang, praktika/ perceptee, tenaga luar/ outsourcing, ataupun lulusan keperawatan yang tidak memiliki Surat Tanda Registrasi (STR). Data demografik tersebut meliputi: jenis kelamin, lama pengalaman kerja, jabatan dan unit kerja saat ini, tingkat pendidikan dan sertifikasi, pengalaman kebencanaan, dukungan keluarga untuk penugasan kebencanaan, dan pelatihan kebencanaan yang pernah diikuti. Data yang telah terkumpul akan dianalisis menggunakan software SPSS 25. Data dianalisis secara univariat dan bivariat.

\section{HASIL DAN PEMBAHASAN}

Hasil penelitian menunjukkan bahwa dari 136 perawat yang bersedia berpartisipasi dalam penelitian, mayoritas responden adalah perempuan sebanyak $77,2 \%$ (98 perawat). Sebelas perawat $(8,1 \%)$ merupakan perawat gawat darurat. Mayoritas responden memiliki pengalaman bekerja dibidangnya antara 5-10 tahun sebanyak 41,2\%.

\section{Tabel 1. Distribusi Frekuensi Responden Berdasarkan Jenis Kelamin, Usia, Bidang Pekerjaan Keprawatan, dan Pengalaman Bekerja Dalam Bidang-nya ( $N=136)$}

\begin{tabular}{llcc}
\hline \multicolumn{1}{c}{ Variabel } & & Frekuensi & Persentase \\
\hline Jenis Kelamin & Laki-laki & 38 & $27,9 \%$ \\
& Perempuan & 98 & $77,2 \%$ \\
Usia (tahun) & $<30$ & 45 & $33,1 \%$ \\
& $30-40$ & 60 & $44,1 \%$ \\
& $>40$ & 31 & $22,8 \%$ \\
Bidang Pekerjaan & Gawat & 11 & $8,1 \%$ \\
Keperawatan & darurat & & \\
& Non Gawat & 125 & $91,9 \%$ \\
Pengalaman Bekerja & Darurat & & \\
Dalam Bidangnya & T Tahun & 49 & $36 \%$ \\
& 5-10 Tahun & 56 & $41,2 \%$ \\
& $>10$ Tahun & 31 & $22,8 \%$ \\
\hline
\end{tabular}

Hasil penelitian menunjukkan bahwa rerata domain keterampilan komunikasi memiliki skor yang paling besar diantara domain kesiapsiagaan lainnya. Median kemampuan komunikasi perawat sebesar 34 dikuti dengan keterampilan beradaptasi dalam situasi yang menyebabkan stres 
sebesar 33. Keterampilan praktis tanggap bencana merupakan keterampilan ketiga yang memilii skor tinggi yaitu 27. Keterampilan mengatasi stres perawat dicatat sebesar 9, hal ini dimunginkan karena dalam kuisioner JDNREI sendiri domain ini hanya berisi 2 pertanyaan.

Tabel 2. Distribusi Rata-Rata Skor Kesiapsiagaan Bencana Perawat (N=136)

\begin{tabular}{lcccc}
\hline \multicolumn{1}{c}{$\begin{array}{c}\text { Variabel } \\
\text { Kesiapsiagaan }\end{array}$} & Median & SD & Min & Max \\
\hline $\begin{array}{l}\text { Keterampilan keperawatan } \\
\text { gawat darurat }\end{array}$ & 24 & 4,349 & 11 & 30 \\
\hline $\begin{array}{l}\text { Keterampilan praktis } \\
\text { tanggap bencana }\end{array}$ & 27 & 6,582 & 13 & 40 \\
\hline Keterampilan komunikasi & 34 & 5,217 & 22 & 40 \\
\hline $\begin{array}{l}\text { Keterampilan mengatasi } \\
\text { Stress }\end{array}$ & 9 & 1,515 & 4 & 10 \\
\hline $\begin{array}{l}\text { Kemampuan bekerjasma } \\
\text { Keterampilan beradaptasi }\end{array}$ & 23 & 2,834 & 14 & 25 \\
\hline dalam situasi stress & 33 & 5,196 & 15 & 40 \\
\hline
\end{tabular}

Hasil analisis menunjukkan bahwa jenis kelamin berhubungan dengan $50 \%$ domain kesiapsiagaan bencana diukur dengan kuisioner JDNREI. Jenis kelamin secara statistik berhubungan dengan Keterampilan keperawatan gawat darurat, keterampilan praktis tanggap bencana, dan keterampilan komunikasi dengan nilai p masing-masing 0,047; 0,013; dan 0,021. Sementara itu Keterampilan mengatasi stress, kemampuan bekerjasama, dan keterampilan beradaptasi dalam situasis yang menimbulkan stress secara statistik tidak berhubungan dengan jenis kelamin perawat $(\mathrm{p}>0,05)$. Variabel usia juga ditemukan tidak memiliki hubungan dengan kesiapsiagaan perawat dengan nilai $\mathrm{p}>0,05$ pada semua domain yang diukur.

Tabel 3. Hubungan Jenis Kelamin Dengan Kesiapsiagaan Bencana (N=136)

\begin{tabular}{|c|c|c|c|c|}
\hline \multirow[t]{2}{*}{ Variabel } & \multirow{2}{*}{ Jenis Kelamin } & \multicolumn{3}{|c|}{ Sikap Terhadap RJP } \\
\hline & & $\mathrm{n}$ & P Value & Mean Rank \\
\hline \multirow{2}{*}{$\begin{array}{l}\text { Keterampilan Keperawatan gawat } \\
\text { darurat }\end{array}$} & Laki-laki & 38 & \multirow{2}{*}{0,047} & 79,25 \\
\hline & Perempuan & 98 & & 64,33 \\
\hline Keterampilan Praktis Tanggap & Laki-laki & 38 & \multirow{2}{*}{0,013} & 81.93 \\
\hline Bencana & Perempuan & 98 & & 63.29 \\
\hline \multirow[t]{2}{*}{ Keterampilan Komunikasi } & Laki-laki & 38 & \multirow{2}{*}{0,021} & 80.91 \\
\hline & Perempuan & 98 & & 63.69 \\
\hline \multirow[t]{2}{*}{ Keterampilan Mengatasi Stress } & Laki-laki & 38 & \multirow{2}{*}{0,462} & 72.32 \\
\hline & Perempuan & 98 & & 67.02 \\
\hline
\end{tabular}




\begin{tabular}{|c|c|c|c|}
\hline \multirow[t]{2}{*}{ Kemampuan Bekerjasma } & Laki-laki & 38 & \multirow{2}{*}{0,258} \\
\hline & Perempuan & 98 & \\
\hline Keterampilan Beradaptasi dalam & Laki-laki & 38 & \multirow{2}{*}{0,205} \\
\hline situasi Stress & Perempuan & 98 & \\
\hline
\end{tabular}

Tabel 4. Hubungan Usia Dengan Kesiapsiagaan Bencana (N=136)

\begin{tabular}{|c|c|c|c|c|}
\hline \multirow[t]{3}{*}{ Variabel } & \multirow{3}{*}{$\begin{array}{l}\text { Usia } \\
\text { (tahun) }\end{array}$} & \multicolumn{3}{|c|}{ Sikap Terhadap RJP } \\
\hline & & n & $\mathrm{P}$ & Mean \\
\hline & & 11 & Value & Rank \\
\hline \multirow{3}{*}{$\begin{array}{l}\text { Keterampilan Keperawatan } \\
\text { gawat darurat }\end{array}$} & $<30$ & 45 & \multirow{3}{*}{0,533} & 63.17 \\
\hline & $30-40$ & 60 & & 70.73 \\
\hline & $>40$ & 31 & & 71.94 \\
\hline Keterampilan Praktis Tanggap & $<30$ & 45 & \multirow{3}{*}{0,870} & 68.03 \\
\hline \multirow[t]{2}{*}{ Bencana } & $30-40$ & 60 & & 70.27 \\
\hline & $>40$ & 31 & & 65.76 \\
\hline \multirow[t]{3}{*}{ Keterampilan Komunikasi } & $<30$ & 45 & \multirow{3}{*}{0,174} & 72.01 \\
\hline & $30-40$ & 60 & & 61.70 \\
\hline & $>40$ & 31 & & 76.56 \\
\hline \multirow[t]{3}{*}{ Keterampilan Mengatasi Stress } & $<30$ & 45 & \multirow{3}{*}{0,132} & 71.64 \\
\hline & $30-40$ & 60 & & 61.58 \\
\hline & $>40$ & 31 & & 77.34 \\
\hline \multirow[t]{3}{*}{ Kemampuan Bekerjasma } & $<30$ & 45 & \multirow{3}{*}{0,153} & 74.83 \\
\hline & $30-40$ & 60 & & 61.24 \\
\hline & $>40$ & 31 & & 73.35 \\
\hline \multirow{3}{*}{$\begin{array}{l}\text { Keterampilan Beradaptasi dalam } \\
\text { situasi Stress }\end{array}$} & $<30$ & 45 & \multirow{3}{*}{0,166} & 76.92 \\
\hline & $30-40$ & 60 & & 62.23 \\
\hline & $>40$ & 31 & & 68.42 \\
\hline
\end{tabular}

Bidang pekerjaan hanya memiliki hubungan dengan domain keterampilan praktis tanggap bencana $p=0,016$. Sementara itu, secara statistik belum dapat dibuktikan bahwa bidang pekerjaan berhubungan dengan lima domain lain dalam kegawatdaruratan bencana. Meskipun bidang pekerjaan secara statistik berpengaruh pada keterampilan praktis tanggap bencana, namun lama bekerja pada bidang tersebut tidak berhubungan dengan semua domain dalam kesiapsiagaan bencana perawat. 
Tabel 4. Hubungan Bidang Pekerjaan Keperawatan

Dengan Kesiapsiagaan Bencana (N=136)

\begin{tabular}{|c|c|c|c|c|}
\hline \multirow[t]{2}{*}{ Variabel } & \multirow[b]{2}{*}{$\begin{array}{l}\text { Bidang Pekerjaan } \\
\text { Keperawatan }\end{array}$} & \multicolumn{3}{|c|}{ Sikap Terhadap RJP } \\
\hline & & $\mathrm{n}$ & $\begin{array}{c}\mathrm{P} \\
\text { Value }\end{array}$ & $\begin{array}{l}\text { Mean } \\
\text { Rank }\end{array}$ \\
\hline \multirow{2}{*}{$\begin{array}{l}\text { Keterampilan Keperawatan gawat } \\
\text { darurat }\end{array}$} & Gawat Darurat & 11 & \multirow{2}{*}{0,276} & 80.86 \\
\hline & Bukan Gawat darurat & 125 & & 67.41 \\
\hline Keterampilan Praktis Tanggap & Gawat Darurat & 11 & \multirow{2}{*}{0,016} & 95.95 \\
\hline Bencana & Bukan Gawat darurat & 125 & & 66.08 \\
\hline \multirow[t]{2}{*}{ Keterampilan Komunikasi } & Gawat Darurat & 11 & \multirow{2}{*}{0,554} & 61.82 \\
\hline & Bukan Gawat darurat & 125 & & 69.09 \\
\hline \multirow[t]{2}{*}{ Keterampilan Mengatasi Stress } & Gawat Darurat & 11 & \multirow{2}{*}{0,864} & 70.36 \\
\hline & Bukan Gawat darurat & 125 & & 68.34 \\
\hline \multirow[t]{2}{*}{ Kemampuan Bekerjasma } & Gawat Darurat & 11 & \multirow{2}{*}{0,859} & 70.50 \\
\hline & Bukan Gawat darurat & 125 & & 68.32 \\
\hline \multirow{2}{*}{$\begin{array}{l}\text { Keterampilan Beradaptasi dalam } \\
\text { situasi Stress }\end{array}$} & Gawat Darurat & 11 & \multirow{2}{*}{0,249} & 81.59 \\
\hline & Bukan Gawat darurat & 125 & & 67.35 \\
\hline
\end{tabular}

Tabel 4. Hubungan Pengalaman di Bidang Pekerjaan-nya Dengan Kesiapsiagaan Bencana ( $\mathrm{N}=136)$

\begin{tabular}{|c|c|c|c|c|}
\hline \multirow[t]{2}{*}{ Variabel } & \multirow[b]{2}{*}{$\begin{array}{l}\text { Lama kerja } \\
\text { (tahun) }\end{array}$} & \multicolumn{3}{|c|}{ Sikap Terhadap RJP } \\
\hline & & $\mathrm{n}$ & $\begin{array}{c}\mathrm{P} \\
\text { Value }\end{array}$ & $\begin{array}{l}\text { Mean } \\
\text { Rank }\end{array}$ \\
\hline \multirow{3}{*}{$\begin{array}{l}\text { Keterampilan Keperawatan gawat } \\
\text { darurat }\end{array}$} & $<5$ & 49 & \multirow{3}{*}{0,533} & 66.01 \\
\hline & $5-10$ & 56 & & 65.71 \\
\hline & $>10$ & 31 & & 77.47 \\
\hline \multirow[t]{3}{*}{ Keterampilan Praktis Tanggap Bencana } & $<5$ & 49 & \multirow{3}{*}{0,870} & 67.29 \\
\hline & $5-10$ & 56 & & 67.06 \\
\hline & $>10$ & 31 & & 73.02 \\
\hline \multirow[t]{3}{*}{ Keterampilan Komunikasi } & $<5$ & 49 & \multirow{3}{*}{0,174} & 68.98 \\
\hline & $5-10$ & 56 & & 67.86 \\
\hline & $>10$ & 31 & & 68.90 \\
\hline \multirow[t]{3}{*}{ Keterampilan Mengatasi Stress } & $<5$ & 49 & \multirow{3}{*}{0,132} & 66.42 \\
\hline & $5-10$ & 56 & & 65.01 \\
\hline & $>10$ & 31 & & 78.10 \\
\hline \multirow[t]{3}{*}{ Kemampuan Bekerjasma } & $<5$ & 49 & \multirow{3}{*}{0,153} & 67.43 \\
\hline & $5-10$ & 56 & & 69.95 \\
\hline & $>10$ & 31 & & 67.58 \\
\hline
\end{tabular}




$\begin{array}{lcccc}\text { Keterampilan Beradaptasi dalam } & <5 & 49 & & 68.20 \\ \text { situasi Stress } & 5-10 & 56 & 0,166 & 67.83 \\ & >10 & 31 & & 70.18\end{array}$

\section{SIMPULAN}

Hasil penelitian menunjukkan bahwa determinan yang secara statistik bidang pekerjaan merupakan determinan yang dominan mempengaruhi kesiapsiagaan bencana perawat. Bidang pekerjaan yang dikelompokkkan menjadi gawat darurat dan non gawat darurat secara statistic terbukti mempengaruhi keterampilan keperawatan gawat darurat, keterampilan praktis tanggap bencana, keterampilan komunikasi, keterampilan mengatasi stress, kemampuan bekerjasama, keterampilan beradaptasi dalam situasi stress.

\section{SARAN}

Pelatihan terkait keterampilan dalam enam domain kesiapsiagaan bencana perlu dilakukan pada semua perawat. Bukan hanya mereka yang bekerja di area gawat darurat yang wajib memiliki kemampuan dan keterampilan dalam kesiapsiagaan bencana, namun seluruh perawat yang merupakan salah satu tenaga kesehatan yang berperan penting dalam manajemen bencana wajib resilien dalam kesiapsiagaan bencana.

\section{DAFTAR PUSTAKA}

Aitken, P., Leggat, P., Robertson, A., Harley, H., Speare, R., \& Leclercq, M. (2009). Pre- and postdeployment health support provided to Australian Disaster Medical Assistance Team members: Results of a national survey. Travel Medicine and Infectious Disease, 7(5), 305-311. https://doi.org/http://dx.doi.org/10.1016/j.tmaid.2009.03.001

Badan Nasional Penanggulangan Bencana. (2019a). Bencana Alam di Indonesia Tahun 2018 Sampai Dengan 2019.

Badan Nasional Penanggulangan Bencana. (2019b). Data Informasi Bencana Indonesia.

Cipta, A. (2018, December 23). Tsunami Selat Sunda, gubernur Banten: Lima pantai terdampak. Tempo.Co. Retrieved from https://nasional.tempo.co/read/1158105/tsunamiselat-sunda-gubernur- banten-lima-pantai-terdampak/full\&view $=$ ok

Costa, M., Oberholzer-Riss, M., Hatz, C., Steffen, R., Puhan, M., \& Schlagenhauf, P. (2015).

Pre-travel health advice guidelines for humanitarian workers: A systematic review. Travel Medicine and Infectious Disease, 13(6), 449-465. https:/ / doi.org/http:/ /dx.doi.org/10.1016/j.tmaid.2015.11.006

Huriah, T., \& Farida, L. N. (2010). Gambaran Kesiapsiagaan Perawat Puskesmas dalam Manajemen Bencana di Puskesmas Kasihan I Bantul Yogyakarta. Jurnal Mutiara Medika, 10(2), 128-134.

Jacobs-Wingo, J. L., Schlegelmilch, J., Berliner, M., Airall-Simon, G., \& Lang, W. (2019).

Emergency Preparedness Training for Hospital Nursing Staff, New York

City, 2012- 2016. Journal of Nursing Scholarship, 51(1), 81-87. https://doi.org/http://dx.doi.org/10.1111/jnu.12425

Maeda, T., Kotera, S., Matsuda, N., \& Edwards, G. (2016). Disaster Readiness among Nurses in Japan: Current Status Following the Great East Japan Earthquake. International Journal of Nursing, 3(1), 15-28. https://doi.org/10.15640/ijn.v3n1a3

Maeda, T., Kotera, S., Matsuda, N., \& Huebner, C. A. (2018). Developing a scale to measure Japanese nurses' individual readiness for deployment to disasters. Nursing and Health Sciences, 20(3), 346-354. https:// doi.org/10.1111/nhs.12572

Mitchell, M. L., McKinnon, L., Aitken, L. M., Weber, S., Birgan, S., \& Sykes, S. (2016). 
Enhancing disaster preparedness of specialty nurses on a national scale. Disaster Prevention and Management, 25(1), 11-26. https://doi.org/http://dx.doi.org/10.1108/DPM-022015-0026

Mitchell, M., Mackie, B., Aitken, L. M., \& McKinnon, L. C. (2014). Evaluation of an Australian nursing partnership to improve disaster response capacity. Disaster Prevention and Management, 23(5), 524-532. https://doi.org/http:/ / dx.doi.org/10.1108/DPM-04-2014-0069

Nazmudin, A. (2020, January 4). Banjir Bandang, Bencana Terparah di Lebak yang Disebabkan Penambangan Ilegal. Kompas.Com. Retrieved from https://regional.kompas.com/read/2020/01/04/17300021/banjir- bandangbencana- terparah-di-lebak-yang-disebabkan-penambangan- ilegal?page=all

Raveis, V. H., VanDevanter, N., Kovner, C. T., \& Gershon, R. (2017). Enabling a Disaster- Resilient Workforce: Attending to Individual Stress and Collective Trauma. Journal of Nursing Scholarship, 49(6), 653-660. https://doi.org/http://dx.doi.org/10.1111/jnu.12340

Rizqillah, A. F. (2019). Disaster preparedness: survey study pada mahasiswa keperawatan universitas harapan bangsa Purwokerto. Medisains, 16(3),

114. https://doi.org/10.30595/medisains.v16i3.3120

Siemon, M., Hackwith, J., \& Monson, K. (2019). Development of a Disaster Nursing Competencies Assessment Instrument for Baccalaureate Nursing Education. Journal of Nursing Education, 58(4), 229-233. https:/ / doi.org/http:/ /dx.doi.org/10.3928/01484834-20190321-08

Soleman, M. K., Nurcahyani, F., \& Munajati, S. L. (2012). Pemetaan Multirawan Bencana di Provinsi Banten. Majalah Ilmiah Globe, 14(1), 46-59. Retrieved from http://jurnal.big.go.id/index.php/GL/article/view/136

Strauss, E. von, Paillard-Borg, S., Holmgren, J., Saaristo, P., von Strauss, E., Paillard-Borg, S., ... Saaristo, P. (2017). Global nursing in an Ebola viral haemorrhagic fever outbreak: before, during and after deployment. Global Health Action, 10(1), 1-11. https:/ / doi.org/http:/ /dx.doi.org/10.1080/16549716.2017.1371427

Veenema, T. G., Griffin, A., Gable, A. R., MacIntyre, L., Simons, N., Couig, M. P., ... Larson, E. (2016). Nurses as Leaders in Disaster Preparedness and Response-A Call to Action. Journal of Nursing Scholarship, 48(2),

187-200. https://doi.org/http://dx.doi.org/10.1111/jnu.12198

Wenji, Z., Turale, S., Stone, T. E., \& Petrini, M. A. (2015). Chinese nurses' relief experiences following two earthquakes: Implications for disaster education and policy development. Nurse Education in Practice, 15(1),

75-81. https://doi.org/http://dx.doi.org/10.1016/j.nepr.2014.06.011

World Health Organization. (2008). Glossary of Humanitarian Terms. Retrieved from https://www.who.int/hac/about/definitions/en/

Wyte-Lake, T., Anne, G., \& Dobalian, A. (2018). Supporting Staff Through a Complete Hospital Evacuation and Extended Displacement Period. Journal of Healthcare Management, 63(3), 195-209.

https:/ /doi.org/http://dx.doi.org/10.1097/JHM-D-16-0000 